\title{
Порівняльна оцінка різних методів закриття ранових дефектів у паціентів із синдромом стопи діабетика
}

\begin{abstract}
Мета роботи: покращити результати хірургічного лікування хворих із синдромом стопи діабетика (ССД) шляхом використання сучасних методів закриття ранових дефектів.

Матеріали і методи. Проведено аналіз результатів комплексного обстеження й лікування 67 хворих із ССД. Пацієнтів поділені на групу порівняння - 31 (46,27 \%) хворий, яким виконано “класичну” автодермопластику, та основну групу - 36 (53,73 \%) хворих. Серед них у 17 (47,22 \%) хворих проведено закриття ранового дефекту за допомогою еквіваленту дерми, а у 19 (52,78 \%) хворих використано РRP методику. Відповідно до клінічних форм ССД виділено невропатичну форму стопи діабетика у 30 (44,78 \%) хворих та нейроішемічну форму стопи діабетика у 37 (55,22 \%) хворих. На підставі отриманих результатів використання різних способів закриття дефектів обчислювали площу та швидкість загоєння ран.

Результати досліджень та їх обговорення. За результатами аналізу застосування еквіваленту дерми встановлено наступне: на 20-ту добу лікування площа рани у 1,76 раза менша від площі рани в пацієнтів без використання еквіваленту дерми; швидкість загоєння рани вища в 1,41 раза. При застосуванні PRP мембрани встановлено, що на 20-ту добу лікування площа рани у 2,25 раза менша від площі рани в пацієнтів без використання PRP мембрани, а швидкість загоєння рани вища в 1,45 раза. Використання клітинно-тканинних технологій та збагаченою тромбоцитами та факторами росту мембрани у місцевому лікуванні ранового дефекту дозволяє досягти загоєння й поліпшує результати лікування за рахунок прискорення строків епітелізації порівняно із традиційною терапією.
\end{abstract}

Ключові слова: цукровий діабет; синдром стопи діабетика; еквівалент дерми; platelet-rich plasma.

Постановка проблеми і аналіз останніх досліджень та публікацій. Цукровий діабет (ЦД) залишається одним із найбільш поширених, високовитратних хронічних захворювань серед неінфекційних хвороб, адже на одинадцять дорослих у світі припадає одна особа з ЦД, при цьому у 90 \% - це другий його тип, а хронічні ранові дефекти нижніх кінцівок виникають більш як у 50 \% хворих на ЦД [1, 2].

В останні роки хірургічне лікування гнійно-некротичних уражень нижніх кінцівок у хворих на ЦД спрямоване на виконання малих ампутацій та хірургічної обробки, суть яких врятувати кінцівку і зберегти ії опорну функцію [9]. Проте проведення таких операцій часто призводить до формування великих ранових дефектів, які важко закрити за допомогою автодермопластики, пластики місцевими тканинами або клаптями на живильних ніжках. Попри технічну простоту методу автодермопластики шкірним трансплантатом, результати його застосування в хірургії далекі від задовільних [3], адже спостерігаються випадки відторгнення трансплантата, його лізис, що призводить не тільки до оголення закритої рани і втрати трансплантата, але і до збільшення ранової поверхні за рахунок донорської ділянки.

На сьогодні для консервативного лікування ранових дефектів використовують найширший спектр засобів, але жоден із них не дає гарантованого клінічного ефекту. Тому актуальним залишається апробація сучасних методів закриття ранових дефектів, які б забезпечували хороший клінічний ефект. Одним із таких способів $є$ використання збагаченої тромбоцитами плазми, яка завдяки високій концентрації факторів росту забезпечує краще відновлення структури ушкоджених тканин $[4,5]$.

Мета роботи: покращити результати хірургічного лікування хворих із синдромом стопи діабетика шляхом розробки сучасних методів закриття ранових дефектів.

Матеріали і методи. Дослідження проводили на базі Волинського обласного госпіталю ветеранів війни за період з 2010 до 2015 р. Дослідження засноване на результатах комплексного обстеження й лікування 67 хворих із ССД.

Пацієнтів розділили на групу порівняння - 31 (46,27 \%) хворий, яким виконано “класичну” автодермопластику, та основну групу - 36 (53,73 \%) хворих. Серед пацієнтів основної групи у 17 (47,22 \%) проведено закриття ранового дефекту за допомогою еквіваленту дерми, а у 19 (52,78 \%) хворих використано PRP методику.

Відповідно до клінічних форм ССД виділено невропатичну форму стопи діабетика (НПФССД) та нейроішемічну форму стопи діабетика (НІФССД) (табл. 1).

За даними таблиці 1 , у структурі хворих із гнійно-некротичними ускладненнями ЦД переважали пацієнти з НІФССД - 37 (55,22 \%) хворих. Наведені дані підтверджують думку більшос- 
Таблиця 1. Розподіл хворих за патогенетичним варіантом синдрому діабетичної стопи

\begin{tabular}{|c|c|c|c|}
\hline \multirow{2}{*}{ Групи } & \multicolumn{2}{|c|}{ Клінічні форми ССД } & \multirow{2}{*}{ Усього } \\
\hline & НІФССД & НПФССД & \\
\hline Порівняння & $15(48,39 \%)$ & $16(51,61 \%)$ & $31(46,27 \%)$ \\
\hline Основна & $22(61,11 \%)$ & $14(38,89 \%)$ & $36(53,73 \%)$ \\
\hline Разом & $37(55,22 \%)$ & $30(44,78 \%)$ & $67(100 \%)$ \\
\hline
\end{tabular}

ті фахівців про те, що ССД належить до категорії пізніх ускладнень ЦД, у генезі якого основними факторами виступають діабетична ангіопатія [6]. Автологічну PRP отримували за методикою J. Choukroun [7]. Формування еквівалент дерми (ЕД) - одержання тривимірного колагенового гелю [8]. Для цього стерильний розчин $\mathrm{NaOH}$, молярна концентрація якого 0,34 моль/л, з'єднували 3 концентрованим живильним середовищем Ігла у співвідношенні 1:2 і додавали необхідну кількість бікарбонату натрію і глутаміну. Отриману суміш з'єднували з охолодженим розчином колагену в оцтовій кислоті в співвідношенні 1:4, після чого поміщали на лід, щоб запобігти швидкій желатинізації колагену. Необхідну аліквоту суспензії клітин додавали у свіжоприготовлену суміш колагену і живильного середовища з розрахунку 6-9х105 кл/мл суміші. Для створення еквіваленту дерми використовували клітини 4-6 пасажу. Отриману суміш поміщали в $\mathrm{CO}_{2}$-інкубатор і культивували при $37{ }^{\circ} \mathrm{C}$ та $5 \% \mathrm{CO}_{2}$. Протягом години відбувалася полімеризація гелю. Першу зміну середовища проводили через 24 години. У якості культурального середовища використовували DMEM 3 10 \% ембріональної телячої сироватки і 50 мкг/мл аскорбату натрію. Еквівалент дерми культивували протягом двох-трьох тижнів для заміщення колагену гелю екстрацелюлярним матриксом, синтезованим de novo фібробластами еквіваленту. Готовий еквівалент дерми заморожували в парах рідкого азоту і зберігали в низькотемпературному морозильнику при $70{ }^{\circ} \mathrm{C}$ до використання. За день до трансплантації ЕД відігрівали на водяній бані, заливали культуральним середовищем і культивували протягом 12-24 годин в стандартних умовах.

На підставі отриманих результатів використання різних способів закриття дефектів обчислювали швидкість загоєння ран за формулою:

$$
\Delta \mathrm{S}=\frac{\mathrm{S}-\mathrm{Si}}{\mathrm{S} \times \mathrm{t}} \times 100,
$$

де $\Delta \mathrm{S}$ - відносна швидкість загоєння рани, \%; $\mathrm{S}$ - величина площі рани при першому вимірі; Si - площа рани при наступних вимірах; $\mathrm{t}$ - кількість днів між першим і наступним вимірами.

Результати досліджень та їх обговорення. При вимірюванні площі ранового дефекту в контрольній групі протягом лікування отримано такі результати швидкості епітелізації (табл. 2, 3).

Таблиця 2. Динаміка зміни площі рани у хворих без використання еквіваленту дерми та PRP мембрани

\begin{tabular}{||l|c|c||}
\hline \multicolumn{1}{|c|}{ Термін лікування } & Параметри & Група порівняння $(\mathrm{n}=31)$ \\
\hline Початок лікування & Площа рани $\left(\mathrm{мм}^{2}\right)$ & $1327 \pm 183,76$ \\
\hline 5 доба & Площа рани $\left(\mathrm{Mм}^{2}\right)$ & $1056 \pm 156,46$ \\
\hline 10 доба & Площа рани $\left(\mathrm{мm}^{2}\right)$ & $837 \pm 124,16$ \\
\hline 15 доба & Площа рани $\left(\mathrm{мм}^{2}\right)$ & $612 \pm 87,59$ \\
\hline 20 доба & Площа рани $\left(\mathrm{мm}^{2}\right)$ & $298 \pm 45,23$ \\
\hline
\end{tabular}

Таблиця 3. Швидкість загоєння в процесі лікування у хворих без використання еквіваленту дерми та PRP мембрани

\begin{tabular}{||c|c|c||}
\hline \multicolumn{1}{|c|}{ Термін лікування } & Параметри & Група порівняння $(\mathrm{n}=31)$ \\
\hline 5 доба & $\Delta \mathrm{S}(\%)$ & $5,87 \pm 0,14$ \\
\hline 10 доба & $\Delta \mathrm{S}(\%)$ & $4,12 \pm 0,12$ \\
\hline 15 доба & $\Delta \mathrm{S}(\%)$ & $4,27 \pm 0,18$ \\
\hline 20 доба & $\Delta \mathrm{S}(\%)$ & $3,45 \pm 0,11$ \\
\hline
\end{tabular}


При вимірюванні площі ранового дефекту еквівалентом дерми в основній групі протягом лікування отримано результати, наведені в таблиці 4. У процесі лікування ми дослідили швидкість епітелізації, дані зміни показника наведено в таблиці 5.
При вимірюванні площі ранового дефекту PRP мембраною в основній групі протягом лікування отримано результати, наведені таблиці 6. У процесі лікування ми дослідили швидкість епітелізації, дані зміни показника наведено в таблиці 7.

Таблиця 4. Динаміка зміни площі рани у хворих із використанням еквіваленту дерми

\begin{tabular}{||l|c|c||}
\hline \multirow{2}{*}{\begin{tabular}{c} 
Термін лікування \\
\cline { 2 - 3 }
\end{tabular}} & \multicolumn{2}{|c||}{$\begin{array}{c}\text { Основна група } \\
\left.\left.\text { (площа рани (мм }{ }^{2}\right)\right)\end{array}$} \\
\cline { 2 - 3 } & НПФССД $(\mathrm{n}=10)$ & НІФССД $(\mathrm{n}=7)$ \\
\hline Початок лікування & $1423 \pm 218,33$ & $1377 \pm 211,34$ \\
\hline 5 доба & $985 \pm 165,87$ & $1023 \pm 171,81$ \\
\hline 10 доба & $635 \pm 102,36$ & $678 \pm 100,35$ \\
\hline 15 доба & $347 \pm 78,57$ & $381 \pm 75,42$ \\
\hline 20 доба & $169 \pm 14,43$ & $182 \pm 12,49$ \\
\hline
\end{tabular}

Таблиця 5. Швидкість загоєння дефекту в процесі лікування у хворих із використанням еквіваленту дерми

\begin{tabular}{||l|c|c||}
\hline \multirow{2}{*}{\begin{tabular}{c} 
Термін лікування \\
\cline { 2 - 3 }
\end{tabular}} & \multicolumn{2}{|c|}{$\begin{array}{c}\text { Основна група } \\
(\Delta \mathrm{S}(\%))\end{array}$} \\
\cline { 2 - 3 } & НПФССД $(\mathrm{n}=10)$ & НІФССД $(\mathrm{n}=7)$ \\
\hline 5 доба & $5,23 \pm 0,12$ & $5,02 \pm 0,15$ \\
\hline 10 доба & $5,48 \pm 0,15$ & $5,11 \pm 0,15$ \\
\hline 15 доба & $5,67 \pm 0,13$ & $4,97 \pm 0,12$ \\
\hline
\end{tabular}

Таблиця 6. Динаміка зміни площі рани у хворих із використанням PRP мембрани

\begin{tabular}{||l|c|c||}
\hline \multirow{2}{*}{\begin{tabular}{c} 
Термін лікування \\
\cline { 2 - 3 }
\end{tabular}} & \multicolumn{2}{|c|}{$\begin{array}{c}\text { Основна група } \\
\left.\text { (площа рани }\left(\mathrm{мm}^{2}\right)\right)\end{array}$} \\
\cline { 2 - 3 } & НПФССД $(\mathrm{n}=12)$ & НІФССД $(\mathrm{n}=7)$ \\
\hline Початок лікування & $1510 \pm 201,36$ & $1602 \pm 198,34$ \\
\hline 5 доба & $945 \pm 158,81$ & $1121 \pm 183,85$ \\
\hline 10 доба & $587 \pm 98,35$ & $682 \pm 102,37$ \\
\hline 15 доба & $298 \pm 77,45$ & $431 \pm 72,42$ \\
\hline 20 доба & $132 \pm 18,43$ & $143 \pm 12,56$ \\
\hline
\end{tabular}

Таблиця 7. Швидкість загоєння дефекту в процесі лікування у хворих із використання PRP мембрани

\begin{tabular}{||l|c|c||}
\hline \multirow{2}{*}{ Термін лікування } & \multicolumn{2}{|c|}{$\begin{array}{c}\text { Основна група } \\
(\Delta \mathrm{S}(\%))\end{array}$} \\
\cline { 2 - 3 } & НПФССД $(\mathrm{n}=12)$ & НІФССД $(\mathrm{n}=7)$ \\
\hline 5 доба & $5,41 \pm 0,12$ & $5,02 \pm 0,15$ \\
\hline 10 доба & $5,56 \pm 0,13$ & $5,23 \pm 0,12$ \\
\hline 15 доба & $5,98 \pm 0,14$ & $4,91 \pm 0,13$ \\
\hline 20 доба & $5,01 \pm 0,15$ & $4,89 \pm 0,14$ \\
\hline
\end{tabular}


Висновки. За результатами аналізу застосування еквіваленту дерми встановлено, що на 20-ту добу лікування площа рани у 1,76 раза менша від площі рани в пацієнтів без використання еквіваленту дерми; швидкість загоєння рани вища в 1,41 раза.

За результатом аналізу застосування PRP мембрани встановлено, що на 20-ту добу лікування площа рани у 2,25 раза менша від площі ра-

\section{СПИСОК ЛІТЕРАТУРИ}

1. Zheng, Yan. Global aetiology and epidemiology of type 2 diabetes mellitus and its complications / Zheng, Yan, Sylvia $\mathrm{H}$. Ley, Frank B. Hu // Nature Reviews Endocrinology. - 2018. Vol. 14 (2). - P. 88.

2. Andrew J. M. Boulton. The global burden of diabetic foot disease / J. M. Boulton Andrew // The Lancet. - 2005. - Vol. 366 (9498). - P. 1719-1724.

3. Zelen C. 45-LB: Results of a pilot evaluation of a novel autologous homologous skin construct treatment of diabetic foot wounds refractory to conventional treatments / C. Zelen, D. G. Armstrong. - 2019.

4. (2019). Autologous platelet-rich plasma for healing chronic venous leg ulcers: Clinical efficacy and potential mechanisms / C. D. Weller, E. E. Gardiner, J. F. Arthur [et al.] // International Wound Journal. - Vol. 16 (3). - P. 788-792.

5. Autologous platelet-rich plasma for nonhealing ulcers: A

\section{REFERENCES}

1. Zheng, Yan, Sylvia H. Ley, Frank B. Hu. (2018). Global aetiology and epidemiology of type 2 diabetes mellitus and its complications. Nature Reviews Endocrinology 14 (2), 88.

2. Boulton, Andrew J.M. (2005). The global burden of diabetic foot disease. The Lancet, 366 (9498), 1719-1724.

3. Zelen, C., \& Armstrong, D.G. (2019). 45-LB: Results of a pilot evaluation of a novel autologous homologous skin construct treatment of diabetic foot wounds refractory to conventional treatments. 4. Weller C.D., Gardiner, E.E., Arthur, J.F., Southey, M., \& Andrews, R.K. (2019). Autologous platelet-rich plasma for healing chronic venous leg ulcers: Clinical efficacy and potential mechanisms. International Wound Journal, 16 (3), 788-792.

5. Tsachiridi, M., Galyfos, G., Andreou, A., Sianou, A., Sigala, F., Zografos, G., \& Filis, K. (2019). Autologous Platelet-Rich Plasma for Nonhealing Ulcers: A Comparative Study. Vascular Specialist ни в пацієнтів без використання PRP мембрани, а швидкість загоєння рани вища в 1,45 рази.

Використання клітинно-тканинних технологій та збагаченою тромбоцитами та факторами росту мембрани у місцевому лікуванні ранового дефекту дає можливість досягти загоєння й поліпшує результати лікування за рахунок прискорення строків епітелізації порівняно із традиційною терапією. comparative study / M. Tsachiridi, G. Galyfos, A. Andreou [et al.] // Vascular Specialist International. - 2019. - Vol. 35 (1). - P. 22. 6. Cheun, T. J. Peripheral Arterial Disease and Diabetes Mellitus. In The Diabetes Textbook / T. J. Cheun, G. M. Haidar, B. Toursarkissian. - Springer, Cham. - 2019. - P. 747-763.

7. Platelet-rich fibrin and soft tissue wound healing: a systematic review / R. J. Miron, M. Fujioka-Kobayashi, M. Bishara [et al.] // Tissue Engineering Part B: Reviews. - 2017. - Vol. 23 (1). P. 83-99.

8. Bello Y. M. Tissue-engineered skin. Current status in wound healing / Y. M. Bello, A. F. Falabella, W. H. Eaglstein // Am. J. Clin. Dermatol. - 2011. - Vol. 2 (5). - P. 305-313

9. Soft tissue reconstruction with diabetic foot tissue loss / A. Hasenstein Todd, Timothy Greene, C. Van Jennifer, Andrew J. Meyr // Clinics in Pediatric Medicine and Surgery. - 2019. Vol. 36 (3). - P. 425-440.

International, 35 (1), 22.

6. Cheun, T.J., Haidar, G.M., \& Toursarkissian, B. (2019). Peripheral Arterial Disease and Diabetes Mellitus. In The Diabetes Textbook. Springer, Cham.

7. Miron R.J., Fujioka-Kobayashi, M., Bishara, M., Zhang, Y., Hernandez, M., \& Choukroun, J. (2017). Platelet-rich fibrin and soft tissue wound healing: a systematic review. Tissue Engineering Part B: Reviews. 23 (1), 83-99.

8. Bello, Y.M., Falabella, A.F., \& Eaglstein, W.H. (2001). Tissue-engineered skin. Current status in wound healing. Am. J. Clin. Dermatol., 2 (5), 305-313

9. Hasenstein, Todd A., Timothy Greene, C., Van Jennifer, Andrew Meyr, J. (2019). Soft tissue reconstruction with diabetic foot tissue loss. Clinics in Pediatric Medicine and Surgery, 36, 3, 425-440. 


\author{
I. YA. DZYUBANOVSKY ${ }^{1}$, R. M. ANTOSHCHUK ${ }^{2}$, A. M. PRODAN ${ }^{1}$ \\ I. Horbachevsky Ternopil National Medical University ${ }^{1}$ \\ Volyn Regional Hospital of War Veterans ${ }^{2}$
}

\title{
COMPARATIVE ASSESSMENT OF DIFFERENT METHODS OF WOUND DEFECTS CLOSURE IN PA- TIENTS WITH DIABETIC FOOT SYNDROME
}

\begin{abstract}
The aim of the work: to improve the results of surgical treatment of patients with diabetic foot syndrome using modern methods of wound defects closure.

Materials and Methods. The results of complex examination and treatment of 67 patients with diabetic foot syndrome were performed. The observed patients were divided into: comparison group - 31 (46.27 \%) patients, who underwent "classic" autodermoplasty and the main group - 36 (53.73\%) patients. Among the last in 17 (47.22 \%) the wound defect was closed with the help of the dermal equivalent, and in 19 (52.78 \%) was used the PRP technique. In accordance with the clinical forms of the diabetic foot syndrome, the neuropathic form was indicated in 30 (44.78 \%) patients and the neuro-ischemic form in 37 (55.22 \%) patients. Based on the results obtained using various methods of defect closure, the area and rate of wound healing were calculated.

Results and Discussion. Analyzing the results of the use of the equivalent of the dermis, the following was established: for 20 days of treatment the area of the wound is 1.76 times smaller than the area of the wound in patients without the use of the equivalent of the dermis; the wound healing rate is 1.41 higher. When using the PRP membrane, it is found that by the 20th day of treatment the wound area is 2.25 times smaller than the wound area in patients without using the PRP membrane, and the wound healing rate is 1.45 higher. The use of cell-tissue technologies and platelet-rich membrane with growth factors in topical wound defect treatment allows healing and improves treatment outcomes by accelerating the time of epithelialization over conventional therapy.
\end{abstract}

Key words: diabetes mellitus; diabetic foot syndrome; dermal equivalent; platelet-rich plasma

\section{И. Я. ДЗЮБАНОВСКИЙํㅛ Р. М. АНТОЩУК², А. М. ПРОДАН}

Тернопольский национальный медицинский университет имени И. Я. Горбачевского МОЗ Украины ${ }^{1}$ Волынский областной госпиталь ветеранов войны

\section{СРАВНИТЕЛЬНАЯ ОЦЕНКА РАЗЛИЧНЫХ МЕТОДОВ ЗАКРЫТИЯ РАНЕВОГО ДЕФЕКТА У ПАЦИЕНТОВ С СИНДРОМОМ СТОПЫ ДИАБЕТИКА}

Цель работы: улучшить результаты хирургического лечения больных с синдромом стопы диабетика (ССД) путем использования современных методов закрытия раневых дефектов.

Материалы и методы. Проведенный анализ результатов комплексного обследования и лечения 67 больных с ССД. Пациентов разделили на группу сравнения - 31 (46,27 \%) больной, которым выполняли “классическую” аутодермопластику, и основную группу - 36 (53,73 \%) больных. Среди них у 17 (47,22 \%) больных проведено закрытие раневого дефекта с помощью эквивалента дермы, а у 19 (52,78 \%) больных использовали PRP методику. В соответствии с клиническими формами ССД выделено невропатическую форму стопы диабетика - у 30 (44,78 \%) больных и нейроишемическую форму стопы диабетика у 37 (55,22\%) больных. На основании полученных результатов использования различных способов закрытия дефектов вычисляли площадь и скорость заживления ран.

Результаты исследований и их обсуждение. Анализируя результаты применения эквивалента дермы установлено следующее: на 20 сутки лечения площадь раны в 1,76 раза меньше площадь раны у пациентов без использования эквивалента дермы; скорость заживления раны выше в 1,41 раза. При применении PRP мембраны установлено, что на 20 сутки лечения площадь раны в 2,25 раза меньше площади раны у пациентов без использования PRP мембраны, а скорость заживления раны выше в 1,45 раза. Использование клеточно-тканевых технологий и обогащенной тромбоцитами и факторами роста мембраны в местном лечении раневого дефекта позволяет достичь заживления и улучшает результаты лечения за счет ускорения сроков эпителизации по сравнению с традиционной терапией.

Ключевые слова: сахарный диабет; синдром стопы диабетика; эквивалент дермы; platelet-rich plasma. 